\title{
Improving Students' English Speaking Proficiency in Saudi Public Schools
}

\author{
Heba Awadh Alharbi
}

English Trainer, Technical Collage for Girls, Saudi Arabia, halharbi10@tvtc.gov.sa; heba999@hotmail.com

$\mid$

In English as a foreign language (EFL) contexts, the absence of authentic language learning situations outside the classroom presents a significant challenge to improving students' English communication skills. Specific obstacles in the learning environment can also result in students' limited use of English inside the classroom. These issues ultimately affect students' English speaking capacity. Focusing on the Saudi EFL context, this paper attempted to identify the causes of Saudi students' low proficiency in English communication and provide some recommendations to address these issues. The most significant findings of the paper were: (1) reforming specific Ministry of Education and Higher Education policies in Saudi Arabia is crucial; (2) the Saudi education system should reinforce the use of contemporary approaches to teaching that emphasise problem solving and critical thinking skills and put students in charge of their own learning; and (3) the ministry should consider converting some Saudi public schools into bilingual schools.

Keywords: Saudi Arabia, English speaking proficiency, EFL context, communication problems, traditional methods

\section{INTRODUCTION}

Mastering another language is not an easy task for either students or teachers, especially in (EFL) context. Thus, obstacles that exist in the teaching/learning process only make second language acquisition (SLA) more complicated. A common obstacle EFL students encounter is the deficiency of communication skills not only in public schools but also among English language graduates from Arab universities who are supposed to be experts in their field (Rabab'ah, 2002). A question must be addressed here: Do stakeholders still assume they are doing their jobs perfectly if their students cannot construct a sentence in English without making mistakes?

This issue highlights the essential role of public schools in enabling students to achieve English proficiency over a 12-year period. Saudi Arabia decided to introduce English as a compulsory subject in elementary schools for the sixth grade only eight years ago and for the fourth and fifth grades as a proposal project in some schools only two years ago (Ministry of Education, 2012a). However, this issue has been evident since the early 1990s, as Abdan's (1991) study on introducing the English language in Saudi public 
elementary schools demonstrates.

With respect to English language instruction in Saudi Arabia, 69\% of Saudi teachers use Arabic in English classrooms, and 60\% claim using Arabic is necessary to reduce time consumed (Alshammari, 2011). This indicates problems with the Saudi educational system as a whole, including teacher training, methods used in classrooms and the explicitness of educational goals. Moreover, because of this preference for using Arabic, Saudi students lack opportunities to practise speaking English in the classroom; in an EFL context, classroom practice is crucial given the lack of opportunities to speak English outside the classroom. Accordingly, this paper will focus on Saudi Arabia as an example of an EFL context and diagnose the dilemma concerning Saudi students' English speaking proficiency. It will also explore ways to improve students' communication skills.

\section{DISCUSSION}

\section{Challenges Saudi Students Face in Communicating in English}

There are several obstacles to achieving desired language outcomes. For instance, all EFL countries, including Saudi Arabia, suffer from a lack of authentic situations outside the classroom for practising English communication skills. This lack increases the vital role of classroom practice in providing students essential opportunities for speaking English. Neither teachers nor students should underestimate these opportunities in the teaching/learning process.

\section{Teachers and Students}

The teaching/learning process is like a triangle inside a circle. Teachers, students and the curriculum form the triangle and their interactions occur within the educational system: The circle. The weakness of one component among these will dramatically affect the entire teaching/learning process.

With respect to learning English, Saudi teachers typically lack any advantage over their students. They experience the same EFL circumstances in public school. When they become university students, they have to learn how to speak English and teach English in only four years. From an English department's perspective, the candidates are qualified based on their secondary school grades, regardless of their English language proficiency (Abbad, 1988). Consequently, students do not require any further training in English before they join an English department, which is an unrealistic assessment of secondary school students' English abilities (Zughoul \& Taminian, 1984). Furthermore, university students are taught the same way as they were in public schools: with no English practice in the classroom. For instance, about one-third of bachelor's degree courses in Arab universities are taught in Arabic (Rabab'ah, 2002). Accordingly, faculty members sometimes cannot recommend graduates for employment because of the graduates' inappropriate level of English language proficiency (Rabab'ah, 2002).

In the classroom, teachers play a central role. Their wishes, styles and instructions control everything that happens in the classroom, and they typically speak most of the 
time. Teachers are the only ones who benefit from this situation with respect to practising speaking English in the classroom. In contrast, students are listeners and receivers of knowledge. Their participation in the classroom is limited to one- or twosentence responses to questions (Jamjoom, 2009). In addition, teachers' negative discourse regarding students' performance on assignments or exams can affect students' motivation and willingness to communicate (Brown, 2007). This increases students' anxiety and creates an unsupportive classroom atmosphere.

Moreover, many teachers use their mother tongue, in this case, Arabic, for different purposes in the classroom, such as clarifying difficult concepts or explaining new vocabulary and grammatical points (Alabdan, 1993; Alnofaie, 2010; Alshammari, 2011). These teachers cover most of the important points in the students' L1. This decreases students' motivation to practise speaking English in the classroom, even with their classmates, as speaking English is not a compulsory procedure. Scholars have thus widely criticised using the L1 in language classrooms because it encourages students to think in the L1 and then translate their thoughts into the L2, which produces deficiencies in students' speaking skills (Richard \& Rodgers, 2001; Shaikh, 1993).

Regarding the role of students in the teaching/learning process, Saudi students may not understand why they should bother to achieve English language proficiency. What do they need English for? In their daily interactions and surroundings, students use Arabic to get what they need. Most local employers also do not require English proficiency. Saudi students can thus communicate effectively in their local context and still obtain a decent job without using English. These important facts help to explain Saudi students' negative attitude towards learning English (Syed, 2003). Thus, any future changes to English language teaching in Saudi Arabia need to address this lack of motivation to ensure adequate SLA as it is going to be stated later in the essay.

\section{The Educational System}

Explicit goals are a substantial aspect of any curriculum. For a curriculum to be successful, it must not only set clear goals but also achieve those goals through its outcomes. As Hammerly (1982) has argued, failing to determine goals is often the main cause of a foreign language program's miscarriage. In Saudi Arabia, the Ministry of Education has developed satisfactory goals for teaching English. However, what processes should be followed to obtain those goals? Do the outcomes of the current educational system achieve those goals? The answer, as the immense gap between Saudi Arabia's economic progress and educational progress, as well as the resulting world criticism, indicates, is obviously no (Elyas \& Picard, 2010).

As previously mentioned, some Saudi public elementary schools introduce English as a subject in the fourth grade - not the first grade. Despite the benefits of early language instruction, Saudi Arabia has seen significant resistance to the introduction of English in elementary grades. Stakeholders are concerned that English language instruction will affect the Islamic or Arabic identity of young students (Elyas, 2008). However, Saudi's educational system goals must respond to international demands for English language proficiency. English proficiency is no longer simply a marker of social status. As 
English is now the undisputed language of science worldwide, Saudi students need English to access a wide range of fields and domains. English language proficiency is also essential to success in business, international trade, and academic life and publishing as it allows speakers to follow the latest developments and articulate one's identity to the whole world (Crystal, 2003).

With respect to determining the success of the Saudi curriculum via student outcomes, excellent results do not necessarily reflect students' aptitude. For instance, exams mainly require students to memorise textbook information and paste it on the exam paper (Syed, 2003). In general, several mistakes in the Saudi educational system allow low proficiency students to achieve excellent results. First, even though composition should require students' creativity and imagination, students are provided a pre-written essay for each composition topic. Students are free to stray from these pre-written essays, but, lacking strong writing skills, no student would dare to change a single word; instead, they memorise the composition topics (Elyas, 2008). Second, sometimes teachers provide summaries for each unit. Third, occasionally teachers allow students to repeat quizzes once or twice until the students receive desirable scores. Finally, if a student fails an English class, he or she still progresses to the next grade as English is among the overridden subjects, which include history and geography for example (Ministry of Education, 2012b). Conversely, if a student fails a non-overridden subject such as Arabic literature or religion, he or she must repeat the whole year. These issues encourage Saudi students' negative attitude towards learning English and make them rely more and more on their only source of information: teachers. In this way, students also fail to discover the learning style or strategy that is appropriate for them (Nunan, 1999).

The Saudi educational system has also underestimated the benefits of using technology in language learning. In EFL contexts, technological devices can provide some of the advantages available in ESL contexts. However, computers, recorders and projectors are alien words in Saudi schools. The rarity of these devices negatively influences students' learning outcomes (Hammerly, 1982).

Boring or stressful classroom environments do not encourage students to be creative or analytical, and tasks that only require students to listen and imitate demotivate them. Students have no responsibilities in the classroom and are negative learners. Even if they have the opportunity to participate, they will not take it, because they are afraid to make mistakes. Furthermore, students are not invested in achieving English language proficiency: Even if they fail, they will progress to the next grade. 


\section{SUGGESTIONS TO IMPROVE STUDENTS' COMMUNICATION SKILLS}

Thus far, this essay has introduced challenges Saudi students face in acquiring English language proficiency. This section will now discuss some solutions for improving Saudi students' speaking proficiency.

\section{Teachers and Students}

The Saudi context is a typical example of the traditional grammar-translation method of teaching which is based on learning grammatical rules then applying them by translating sentences from L2 to L1(Elyas \& Picard, 2010). However, teachers should adopt the more appropriate communicative language teaching (CLT) approach which emphasizes interaction as both the means and the ultimate goal of study (Nunan, 1999).

To eliminate difficulties in the classroom. For instance, in the classroom, teachers and students should only communicate in English. In this way, students can improve their speaking skills through real practice, as they would in an ESL context (Brown, 2007). As Alshammari (2011) argues, using an L1 in English classes can be useful, but teachers should use the L1 wisely and as a last resort to clarify complex grammatical norms and vocabulary items. Krashen (1981) also suggests teachers should decrease their L1 use when teaching another language. By university, subjects such as history, geography and religion should be taught entirely in English (Rabab'ah, 2002).

In addition to favouring the traditional grammar-translation method of teaching, Saudi public schools typically do not employ successful contemporary techniques such as pair work, group work, role-playing and interviews. These techniques encourage shy students to participate and discuss their opinions with their classmates instead of only with teachers. Employing various techniques in the classroom also challenges students and caters to the diversity of students' learning styles (Brown, 2007). Moreover, adopting CLT techniques can generate a friendlier and warmer supportive atmosphere in the classroom by building good relationships between Saudi teachers and students and among students. Rather than promoting negative discourse, CLT encourages selfactualisation through positive feedback (Brown, 2007). Making mistakes should not be a scary issue for students. Instead, students should see mistakes as a natural part of the learning process. Teachers should explicitly address this matter to make students aware that they are in a comfortable and secure space (Alshammari, 2011; Brown, 2007). Such an environment will encourage participation and positive attitudes towards learning.

With respect to classroom roles and dynamics, teachers should be facilitators of knowledge in the classroom - not transmitters (Harmer, 2007). In other words, through observation, teachers should help students discover themselves and find their own paths. This is a marvellous way to focus on the students and enable teachers to guide students along their learning journey and improve their awareness (Mynard, 2006). Moreover, as students are the core of the teaching/learning process, curriculum design and teaching approaches should acknowledge and respond to students' needs and learning styles (Graves, 2000). So adapting lessons for students will help in keeping them engaged.

International Journal of Instruction, January $2015 \bullet$ Vol.8, No.1 
According to contemporary approaches, teachers should teach students how to learn not what to learn - by equipping them with metacognitive skills such as preparing and planning, which could save students time and effort. Likewise, familiarising students with different learning styles and techniques could enable students to decide which approach is appropriate for a given task. Teachers should also teach students how to monitor their learning and become aware of the reasons behind their success or failure. This awareness can enable students to evaluate their performance and confirm positive learning behaviours or modify negative behaviours in the future (Griffiths, 2008). Consequently, students will take charge of their learning, become decision makers and govern the whole process, becoming autonomous learners (Harmer, 2007; Rubin \& Thompson, 1994).

Some could argue that such autonomy equates to teachers abandoning their responsibilities and giving them to their students. Indeed, there is a small shift in the classroom roles in such scenarios, and students need to do a lot to get involved in their learning. Nevertheless, teachers still play a significant role in the classroom. This new role requires great effort on the teacher's part with respect to preparing students to reach this point of involvement in their learning. Students must be self-confident and willing to communicate because their opinions and experiences are valuable in this scenario (Nunan, 1999). This shift in roles also significantly improves students' intrinsic motivation in learning the English language, which is the most important type of motivation as interest and self-determination provide long-term motivation (Griffiths, 2008).

The suggestions provided thus far should contribute significantly to changing Saudi students' attitudes towards learning English, which is a crucial issue that curriculum design should address (Graves, 2000). Beyond students' attitudes, one of the most common challenges students in EFL contexts encounter is an apparent lack of authentic language situations outside the classroom. However, authentic situations are always accessible. For instance, teachers could require weekly reflective reports based on any practical use of English outside the classroom, such as ordering a meal in a restaurant, talking to a nurse in a hospital, watching a YouTube clip, watching a TV program or reading any piece of text written in English. Such assignments enable students to practise their language skills outside the classroom and reflect not only in writing but also through oral presentations in the classroom.

As the proposed reflective report assignment demonstrates, learners in EFL contexts can use various methods outside the classroom to acquire another language. For instance, Benson and Nunan (2005) discussed the case of Hamad, an Arabic medical student who achieved an excellent speaking ability by reading English materials. $\mathrm{He}$ believed that a person should keep reading despite any obstacles: Even if the reader encounters unfamiliar vocabulary, he or she should just ignore those words and continue reading, unless they are essential to understanding the whole sentence. Likewise, Stevick (1989) presented the case of Chuck, who achieved a high level of proficiency in Danish by watching television programs and reading newspapers. Initially, he did not understand everything he heard or read, but, gradually, he understood the system after 
six months and his progress continued. So teachers should tell their students about different ways to develop their skills outside the classroom to support the curriculum outcomes. Both teachers and students can improve the overall issue of English language proficiency in Saudi Arabia by becoming more involved in the teaching/learning process and by creating an artificial ESL context.

\section{The Educational System}

The Saudi educational system must consider Saudi students' language needs when setting its learning goals. For instance, students need to achieve efficiency in all four English language skills: speaking and listening, to communicate successfully with English speakers, and reading and writing, to gain access and contribute to various careers. The curriculum should address these skills. Likewise, although language forms are important aspects in teaching English, the curriculum should not overemphasise language forms as if they were the only thing students should master. In contrast, teachers should introduce language forms through communicative tasks. By using a schema building process that depends on students' prior experiences, this process will gradually produce a high level of proficiency in both forms and communication (Nunan, 1999). With respect to communicative tasks, authenticity is an important factor not only in selecting curriculum topics but also in picking real world tasks that are appropriate for the Saudi context. For example, responding to a party invitation is very irrelevant to this context but writing a CV or completing a job application would be relevant (Graves, 2000). Accordingly, the curriculum should address practical skill.

In addition to reassessing its English language curriculum and goals, the Saudi educational system must reconsider introducing the English language in the first grade (Abdan, 1991). Teaching English in elementary schools is no longer an option - it is a necessity. The Saudi educational system must change the curriculum to (1) benefit from the youngest age factor, that is, the younger learners are, the easier language acquisition will be (Nunan, 1999); and (2) equip their students with a fundamental communication tool for following progress in different domains worldwide (Crystal, 2003).

Likewise, the educational system must reassess its concerns regarding English language learning and Islamic or Arabic identity. Anxiety concerning the influence of another language on students' identity should not be an issue. Moreover, it is a religious aim for Muslims to learn other languages. As Prophet Mohammad, peace be upon him, said over 1400 years ago in the Hadith, 'He whoever learns other people's language will be secured from their cunning' (Elyas \& Picard, 2010). Accordingly, there is no conflict between language learning and the Islamic or Arabic identity. Otherwise, Prophet Mohammad, peace be upon him, would not give this advice to his nation.

Two contemporary examples also support the idea of 'no conflict of interest' between language learning and Islamic identity. Moez Masoud, a religious leader who uses both Arabic and English quite well, graduated with a bachelor's degree in economics from an American university in Cairo. In 2011, The Economist described Masoud as one of the world's five most influential Muslim preachers (Moez Masoud, 2013). Likewise, Islamic singer Maher Zain is a Lebanese immigrant in Sweden who holds a bachelor's 
degree in aeronautical engineering (Maher Zain, 2013). The previous examples indicate losing one's Islamic or Arabic identity is a matter of personal choice. Both Masoud and Zain have experienced significant exposure to the English language and have educational backgrounds that totally differ from their chosen careers, but they dedicated their lives to spreading the message of Islam. One might also consider the case of Canada, where French is taught as a second language in elementary schools with no negative effect on students' mother tongue or general performance (Stern et al., 1976).

Concerning accurately measuring student outcomes and determining the success of the Saudi curriculum, the educational system should teach English as a language and not as a subject that can be broken into components to be memorised and regurgitated for exams. Thus, passing an English class should depend on the quality of the students' outputs, or their proficiency and competence, instead of the quantity of their outputs, or how much a student got on an exam. The Saudi Ministry of Education should also review its policy regarding overridden subjects.

With respect to the use of technological devices in Saudi schools, appropriate devices should be made available in all public schools. Qualified experts should also train teachers on their usage. These devices are vital in providing variety in teaching methods and showing models of native speakers (Liton, 2012).

The Saudi educational system might also converting some public schools into bilingual schools, while still teaching specific courses in Arabic, is another option that the Saudi education system must consider to promote English mastery that this has been tried in the Emirates since 2011/12 at some public schools at a first stage to be completed by 2016 at all public schools (Gallagher, 2011). This is an enormous undertaking, as it requires a good budget and strategy, but the project would inflict no harm if the Saudi educational system invests enough in the process to reap strong results. The Saudi government would also save money in the long run with respect to the huge number of students who are sent to study English abroad. Obviously, this project will not be easy, but it is not impossible if gradual changes are made and the government takes other countries' comparable experiences in running bilingual schools into account. Teaching several subjects in English is a good method for mastering the language (Nasr \& Knight, 1987). Studies on some U.S. institutes where teachers teach all subjects in a foreign language also indicate students' achieve improved capacity in the language of instruction (Oneto, 1968; Vocolo, 1967). The development of bilingual schools will ensure Saudi students achieve effective English language proficiency while protecting local culture and keeping students at home.

In addition, the Ministry of Education should allocate a portion of its budget to establishing a research centre that contributes to all aspects relating to educational matters based on statistics and studies in the field. This will ensure any decisions made by the ministry will be on the right path (Syed, 2003).

\section{CONCLUSION}

This essay discussed the dilemma of Saudi public school students' deficiency in English communication competence by drawing on a review of the literature and personal 
experience in the field. It explored the possible causes of this deficiency and approached some resolutions that stakeholders might consider applying in the future. These resolutions are as follows:

- English departments in Saudi universities should reform their policies to guarantee quality in the training of future Saudi teachers.

- The Ministry of Education should reframe its English language learning goals in public schools to ensure Saudi students can compete in international domains. In addition, the ministry should rewrite its testing policies to emphasise quality over quantity in examinations.

- Students will benefit from the young age factor in SLA if the ministry introduces English as a compulsory course in the first grade in public elementary schools.

- Teachers should adopt contemporary teaching methods that appreciate students' needs and learning styles and encourage stress-free classrooms that engender positive attitudes towards language learning, such as the CLT approach.

- Teachers should encourage Saudi students to take charge of their learning by helping them discover what they are capable of. It is the teachers' duty to guide students at this stage to develop self-awareness. This is a significant issue when teachers cannot meet students' diverse needs in the classroom.

- Authenticity and technological devices are essential in creating a lively classroom and avoiding boring textbooks and tasks.

- Implementing some of these changes will improve students' motivation to learn English and change their attitude towards language learning.

- The government should consider the long-term option of transforming some public schools into bilingual schools. This could save money that would otherwise be spent to send Saudi students abroad to study the English language

- Founding a research centre will enable stakeholders to keep an eye on every new matter in the field and provide statistics and studies to help inform stakeholders' decisions.

Improving students' English speaking proficiency in Saudi public schools requires the total cooperation and dedication of teachers, students and the Saudi educational system. Without modifying every element of the triangle and the circle, true success is impossible. This essay has provided some general suggestions that each stakeholder might consider, but further research needs to be conducted in this area. In particular, converting Saudi public schools into bilingual schools will be a big undertaking and require perfect planning.

\section{REFERENCES}

Abbad, A. (1988). An analysis of communicative competence features in English language text in Yemen Arab Republic. Unpublished doctoral dissertation, University of Illinois at Urbana-Champaign, Champaign. 
Abdan, A. A. (1991). An exploratory study of teaching English in the Saudi elementary public schools. System, 19(3), 253-266.

Alabdan, A. (1993). A study in using Arabic in teaching English in Saudi intermediate schools. King Saud University Magazine, 50(2), 396-426.

Alnofaie, H. (2010). The attitude of teachers and students towards using Arabic in EFL classrooms in Saudi public schools - a case study. Novitas-ROYAL, 4(1), 64-95.

Alshammari, M. M. (2011). The use of the mother tongue in Saudi EFL classrooms. Journal of International Educational Research, 7, 95-102.

Benson, P., \& Nunan, D. (2005). Learners' stories: Difference and diversity in language learning. Cambridge: Cambridge University Press.

Brown, H. D. (2007). Teaching by principles: An interactive approach to language pedagogy. New York: Personal Education. Inc.

Crystal, D. (2003). English as a global language. London: Cambridge University Press.

Elyas, T. (2008). The attitude of American English within the Saudi education system. Novitas-ROYAL, 2(1), 28-48.

Elyas, T., \& Picard, M. (2010). Saudi Arabian educational history: Impacts on English language teaching. Education, Business and Society: Contemporary Middle Eastern Issues, 3(2), 136-145. doi:10.1108/17537981011047961

Gallagher, K. (2011). Bilingual education in the UAE: Factors, variables and critical questions. Education, Business and Society: Contemporary Middle Eastern Issues, 4(1), 62 79.

Graves, K. (2000). Designing a language course: A guide for teachers. Boston: Heinle\&Heinle.

Griffiths, C. (2008). Lessons from good language learners. Cambridge: Cambridge University Press.

Hammerly, H. (1982). Synthesis in second language teaching: An introduction to linguistics. Blaine, WA: Second Language Publication.

Harmer, J. (2007). The practice of English language teaching. Harlow, UK: Pearson Education.

Jamjoom, M. I. (2009). Female Islamic studies teachers in Saudi Arabia: A phenomenological study. Teaching and Teacher Education, 20, 1-12.

Krashen, S. (1981). Second language acquisition and second language learning. Oxford: Pergamon.

Liton, H. A. (2012). Developing EFL teaching and learning practices in Saudi colleges: A review. International Journal of Instruction, 5(2), 129-152.

Maher Zain. (2013.). In Wikipedia. Retrieved October 15, 2013 from HYPERLINK "http://en.wikipedia.org/wiki/Maher Zain" http://en.wikipedia.org/wiki/Maher_Zain

Ministry of Education, English Department. (2012a). Teaching English language course. (No. 912/9-2). 
Ministry of Education, English Department. (2012b). Testing mechanism for intermediate and secondary grades (boys-girls). (No. 1/32231207)

Moez Masoud. (2013). In Wikipedia. Retrieved October 15, 2013 from HYPERLINK http://en.wikipedia.org/wiki/Moez_Masoud

Mynard, J. (2006). Promoting learner autonomy in the UAE and Japan. Independence, 39, 17-18. $\quad$ Retrieved from http://lasig.iatefl.org/uploads/1/1/8/3/11836487/seiten_aus_indepe ndence_39.pdf

Nasr, R. T., \& Knight, A. (1987). Teaching and learning English: Selected and simplified readings. Longman.

Nunan, D. (1999). Second language teaching and learning. Boston: Heinle \& Heinle.

Oneto, A. J. (1968). FLES evaluation: Language skills and pupil attitudes in Fairfield, Connection public schools. Conn.: Connection State Department of Education, Bulletin no. 106.

Rabab'ah, G. (2002). Communication problems facing Arab learners of English. Journal of Language and Learning, 3(1), 180-197.

Richard, J. C., \& Rodgers, T. S, (2001). Approaches and methods in language teaching. New York: Cambridge University Press.

Rubin, J., \& Thompson, I. (1994). How to be a more successful language learner: Toward learner autonomy. Boston: Heinle \& Heinle.

Shaikh, A. (1993). Methods of teaching English as a foreign language: A comparative study of traditional and modern approaches. Lahore, Pakistan: Carvan Book House.

Stern, H. H. et al. (1976). Three approaches to teaching French. Toronto: Ontario Ministry of education.

Stevick, E. W. (1989). Success with foreign languages: Seven who achieved it and what worked for them. New York: Prentice Hall.

Syed, Z. (2003). TESOL in the Gulf: The sociocultural context of English language teaching in the Gulf. TESOL Quarterly, 37(2), 337-341. doi:10.2307/3588508

Vocolo, J. M. (1967). The effect of foreign language study in the elementary school upon achievement in the same language in high school. Modern Language Journal, 55, 463-469.

Zughoul, M., \& Taminian, L. (1984). The linguistic attitude of Arab university students: Factorial structure and intervening variable. The International of the Sociology of Language, 50, 155-179.

\section{Turkish Abstract}

Suudi Devlet Okullarında Öğrencilerin İngilizce Konuşma Yeterliklerinin Geliştirilmesi

İngilizcenin yabancı dil olduğu durumlarda, sınıf dışında gerçekçi bir dil öğrenme ortamının yokluğu öğrencilerin İngilizce iletiş̧im becerilerinin gelişmesinde önemli bir engel teşkil etmektedir. Öğrenme ortamlarındaki belirli engeller ayrıca öğrencinin sınıf içi İngilizce kullanımında da olumsuz bir durum oluşturmaktadır. Bu durumlar nihai anlamda öğrencilerin İngilizce konuşma kapasitelerini de etkilemektedir. Suudi İngilizce öğretimi bağlamına odaklanarak bu çalışma Suudi öğrencilerin İngilizce iletişimde düşük yeterlik düzeylerinin 
sebeplerini belirlemeyi ve bu konuya ilişkin bazı öneriler sunmayı amaçlamaktadır. Çalışmanın en önemli bulguları şu şekildedir: (1) Suudi Arabistan'da eğitim bakanlığı ve yüksek öğretimde belirli politikalarda reform hayatidir; (2) Suudi eğitim sistemi problem cözmeyi, kritik düşünme becerilerini ve öğrencinin kendi öğrenmesinden sorumlu olmayı vurgulayan çağdaş öğretme yaklaşımlarının kullanımını teşvik etmelidir; ve (3) bakanlık bazı Suudi devlet okullarını çift dilli okullara çevirmelidir.

Anahtar Kelimeler: Suudi Arabistan, İngilizce Konuşma Yeterliği, Yabancı dil olarak İngilizce, İletişim problemleri, Geleneksel yöntemler

\section{French Abstract}

\section{L' Amélioration de la Compétence Parlante anglaise d'Étudiants à Écoles Publiques saoudiennes}

Dans l'anglais langue étrangère (EFL) des contextes, l'absence de situations d'apprentissage des langues authentiques à l'extérieur de la salle de classe présente un défi significatif à l'amélioration des compétences de communication anglaises des étudiants. Des obstacles spécifiques dans l'environnement apprenant peuvent aussi aboutir à l'utilisation limitée des étudiants d'anglais à l'intérieur de la salle de classe. Ces questions affectent en fin de compte la capacité parlante anglaise des étudiants. En se concentrant sur le contexte EFL saoudien, ce papier a essayé d'identifier les causes de la compétence basse des étudiants saoudiens dans la communication anglaise et fournir quelques recommandations pour aborder ces questions. Les découvertes les plus significatives du papier étaient : (1) le Ministère de l'Éducation nationale spécifique reformant et des politiques d'Enseignement supérieur dans l'Arabie Saoudite sont cruciaux; (2) le système éducatif saoudien devrait renforcer l'utilisation d'approches contemporaines à l'enseignement qui soulignent la résolution de problèmes et des compétences pensantes critiques et mettent des étudiants responsable de leur propre apprentissage; et (3) le ministère devrait envisager de convertir quelques écoles publiques saoudiennes dans des écoles bilingues.

Mots-clés: l'Arabie Saoudite, Anglais Parlant Compétence, EFL Contexte, Problèmes de Communication, Méthodes Traditionnelles

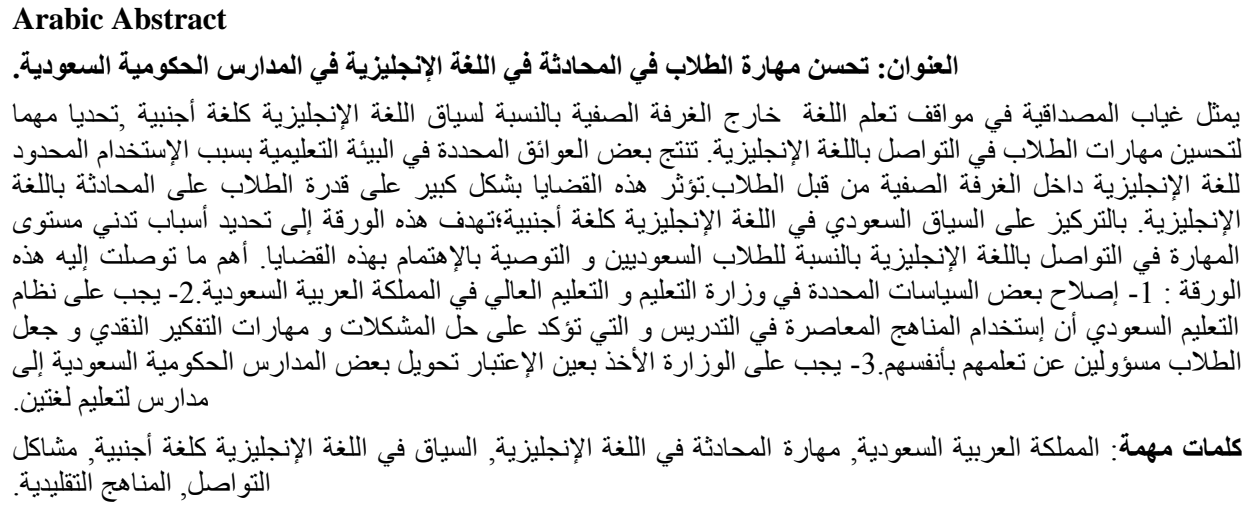

